\title{
Technology-enhanced Learning in Indonesian EFL classes: The Case of Videoscribe
}

\author{
Muhammad Aswad ${ }^{1 *}$, Abd. Hakim Yassi², Nasmilah Nasmilah ${ }^{2}$, Abidin \\ $\mathrm{Pammu}^{2}$ \\ ${ }^{1}$ Departement of English Education, Universitas Sulawesi Barat, Majene, Indonesia \\ ${ }^{2}$ Faculty of Cultural Science, Universitas Hasanuddin, Indonesia \\ *Corresponding author. Email: aswad@unsulbar.ac.id
}

\begin{abstract}
The long-term goal of this research; (1) Providing information to educators about the benefits of applying Videoscribe software as a technology to learn English, (2) providing information on the extent to which Videoscribe can improve student learning outcomes in English, (3) To describe the steps for implementing internet-based learning media with videoscribe software. Specific objectives in this study; (1) obtaining a description of the software, (2) providing information to teachers how to make effective learning by using technology, (3) educational institutions including educators to improve self and more proactive in making and using the right methods in the teaching and learning process so that the educational goals contained in the Education law can be well realized. The study conducted at the Tsanawiah Banua Sendana Madrasah, West Sulawesi, Majene Regency. Data will be processed by using Software; SPSS 21.0. In this research can be concluded that the use of scribe video applications in the learning process in MTs Banua Sendana students after being treated can improve students' English skills. This is evident in the results of the experimental class posttest which is higher than the value in the class or control group $(85.00>79.00)$. so, it was concluded that the use of the video scribe software was very effective for improving students' English skills.
\end{abstract}

Keywords: Student Learning Outcomes, Videoscribe Software, Technology, Education

\section{INTRODUCTION}

Science always develops and progresses very rapidly, according to the times and the development of human thinking [1]. The Indonesian nation as one of the developing countries will not be able to progress as long as it has not improved the quality of our nation's human resources. The quality of life of the nation can increase if it is supported by an established education system. With an established education system, it allows us to think critically, creatively and productively. In the 1945 Constitution it is stated that our country wants to create a smart society. To reach a smart nation, learning communities must be formed from all subjects in the school, including English subjects which are currently subject to programming. Learning English in Indonesia has been supplied as optimally and systematically as feasible at this moment, as proven by English being an obligatory subject in adaptable subject groupings, although it is still not equitably distributed. It's important to distinguish between English education in an urban context and English education in a rural one. Excellent facilities, highly trained teachers, supplemental resources, and, in certain cases, unique rooms designated as English laboratory rooms assist students in learning English in urban schools. It has a significant influence on the pupils' English education results at school.

Whereas English education in suburban schools has limited resources, including just books and instructors as guides, books in English classes are confined to textbooks and student worksheets (LKS). As a result, the learning outcomes of English topics attained are also rated. As a result, the average learning results of the English topics achieved are likewise graded lower [8]. Tsanawiah Madrasah DDI Banua Sendana is a tiny suburban school in the Majene Regency with a diverse student body, including students who are academically challenged. 
The lack of excitement among students is related to inefficient learning procedures, and the content provided by instructors (educators) is less innovative, especially in English, where the English teacher at the Tsanawia Banua Sendana Madrasah still utilizes the old lecture and practice method. As a result, many youngsters are unable to converse, communicate material, or tell a story. As a result, numerous students discover it hard to recognise what the teacher is saying, which has a substantial influence on students' motivation and classroom learning outcomes. In order for students with current constraints to attain the intended learning goals, something that can improve learning outcomes in English is needed. Studying media required for learning English at the Tsanawiah DDI Madrasah Banua Sendana includes videoscribe apps, which are aimed to enhancing student motivation and learning results.

Learning media with videoscribe application is an effective medium for teaching internet-based English to display material through videoscribe. The usage of a variety of learning media in the classroom can help pupils grasp the lessons and become more engaged in the subject that will be presented, such as when the author applies audiovisual learning media, namely videos on English language material, students will be active and enthusiastic and easy to understand the subject matter through videos that are displayed because they will use effective learning media. This will have a positive impact on students' motivation and learning outcomes, especially English subjects.

\section{METHOD}

The research was carried out in Banua Sendana Madrasah in Majene Regency, West Sulawesi Province. This school was chosen intentionally (purposively) based on several factors, including: 1) a sufficient quantity of English language instructors, 2) a sufficient quantity of pupils required, expressed as a proportion of their interest in studying English, and 3) the instructors' methods are less innovative and creative. A Quasy Experimental Design research technique is used in the study "Videoscribe software as a tool for EFL learners", in which this study uses a model of two groups pretest-posttest design, based on the challenges mentioned in this study. The research methodology used in this work is a comparison group research model." As a consequence, the treatment results may be predicted more precisely since it can be compared to the circumstances before treatment and the methods used by the English instructor. Samples and Data Collection Methods.
For the purposes of this study, samples were obtained from Based on the Administration of Tsanawia Banua Sendana Madrasah Majene district. In this study, 33 students from class XIII A, 31 students from class XIII B, and 30 students from class XIII C were used as examples. So, the total number of class VIII at Tsanawiah DDI Banua Sendana Madrasah is 94 students. The instruments used in this study were observation and tests of participants' learning outcomes. Data analysis techniques to calculate research results or English learning outcomes of students using the percentage formula [8] as follows:

$$
P=\frac{F}{N} \times 100
$$

where:

P: percentage of value obtained

$\mathrm{f}$ : the frequency that the percentage is looking for $\mathrm{N}$ : Many individuals / numbers of individuals

Whereas to find out the changes in learning outcomes through the pretest and posttest used the t-test, to find out the t-test the researchers used the SPSS 21.0 data processing application program.

\section{RESULT}

Based on the frequency distribution of the descriptive statistics below, it is clear that the minimum and maximum scores from the pretest and posttest in the experimental class. The results of the students 'scores indicate that there are differences or significant increases in students' English skills before and after being given treatment or teaching using the video scribe application. This is reinforced from the results of the table 4.1 showing the lowest value at pretest obtained a value of 55.00 with a low category while the value in the posttest obtained a value of 75.00 with a medium category while for the value of English at the minimum posttest obtained a value of 75.00 and the highest value 85.00 with a high category.

It can be seen that there are differences before and after the learning process or treatment using the video scribe application media, by which it can be concluded that the use of scribe videos can improve the learning achievement and motivation of Banua Sendana's MTS DDI students. 
Table 1. Statistic Descriptive in pretest and Posttest of Experiment Class

Descriptive Statistics

\begin{tabular}{|l|r|r|r|r|r|}
\hline & $\mathrm{N}$ & Minimum & Maximum & Rata-rata & \multicolumn{1}{|c|}{ Std. Deviasi } \\
\hline Pretest & 30 & 55.00 & 75.00 & 65.1667 & 6.75729 \\
Posttest & 30 & 75.00 & 85.00 & 80.8333 & 2.96047 \\
Valid N (listwise) & 30 & & & & \\
\hline
\end{tabular}

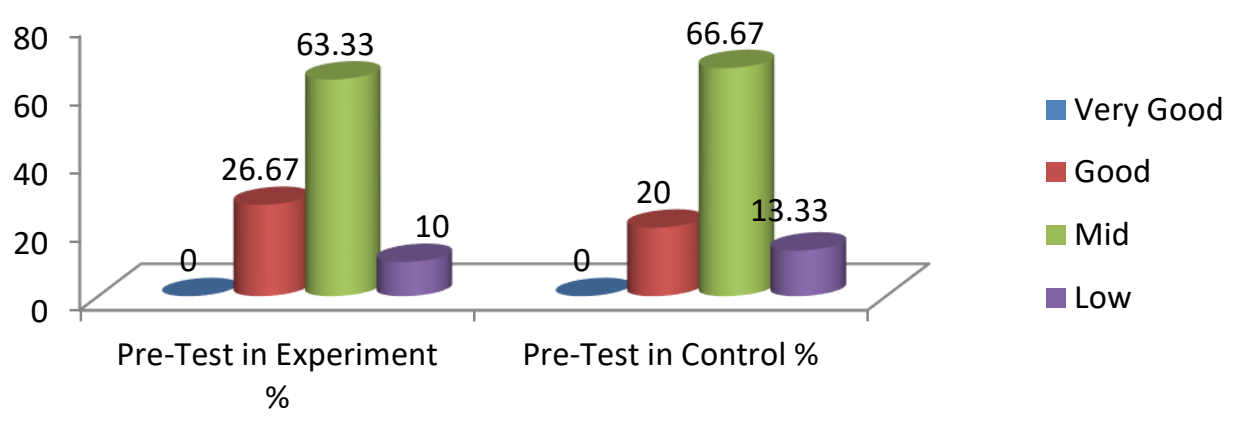

Figure 1 Histogram test pretest experiment group

Table 2. Statistic Descriptive pretest and Posttest control group

Descriptive Statistics

\begin{tabular}{|l|r|r|r|r|r|}
\hline & $\mathrm{N}$ & Minimum & Maximum & Rata-rata & Std. Deviation \\
\hline Pretest & 30 & 55.00 & 75.00 & 63.6667 & 5.71346 \\
Posttest & 30 & 60.00 & 79.00 & 66.3333 & 5.26100 \\
Valid N (listwise) & 30 & & & & \\
\hline
\end{tabular}

Based on the frequency distribution of the statistical description table 4.2 above, the experimental class's minimum and maximum scores from the pretest and posttest are obvious. The results of the students 'scores show that there is no significant increase in students' English skills before and after being given treatment or teaching. This is obvious from the findings of table 4.2 , which indicate that the lowest value on the pretest was 55.00, and the greatest value on the posttest was 60.00 with a low category, while the value of English on the minimum posttest was 75.00 , and the highest value was 75.00 with a medium category.

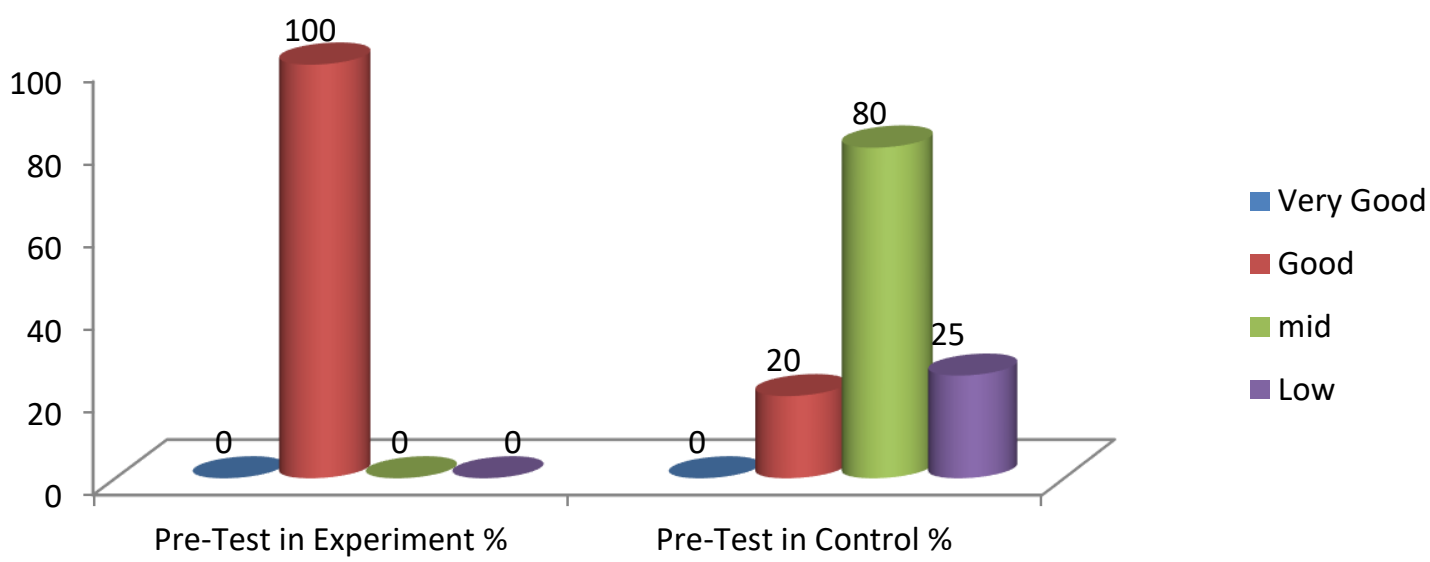

Figure 2 Histogram pretest control Group 
Table 3. Independent Sample t-test of Pretest

\begin{tabular}{|c|c|c|c|c|c|c|c|c|c|}
\hline \multicolumn{10}{|c|}{ Independent Samples Test } \\
\hline & \multicolumn{2}{|c|}{$\begin{array}{l}\text { Levene's Test for } \\
\text { Equality of Variances }\end{array}$} & \multicolumn{7}{|c|}{$\mathrm{t}$-test for Equality of Means } \\
\hline & \multirow[b]{2}{*}{$\mathrm{F}$} & \multirow[b]{2}{*}{ Sig. } & \multirow[b]{2}{*}{$t$} & \multirow[b]{2}{*}{ df } & \multirow[b]{2}{*}{$\begin{array}{l}\text { Sig. }(2- \\
\text { tailed })\end{array}$} & \multirow[b]{2}{*}{$\begin{array}{c}\text { Mean } \\
\text { Difference }\end{array}$} & \multirow[b]{2}{*}{$\begin{array}{l}\text { Std. Error } \\
\text { Difference }\end{array}$} & \multicolumn{2}{|c|}{$\begin{array}{l}\text { 95\% Confidence } \\
\text { Interval of the } \\
\text { Difference }\end{array}$} \\
\hline & & & & & & & & Lower & $\begin{array}{c}\text { Uppe } \\
r\end{array}$ \\
\hline $\begin{array}{l}F \text { Equal } \\
r \text { variances } \\
\text { e assumed } \\
t \text { Equal } \\
\text { e variances not } \\
s \text { assumed } \\
t\end{array}$ & .560 & .457 & .928 & 56.440 & .357 & 1.50000 & 1.61560 & -1.73397 & $\begin{array}{r}4.73 \\
397 \\
\\
4.73 \\
587\end{array}$ \\
\hline
\end{tabular}

The value of the independent sample t-test is shown in Table 4.3, which is based on the analysis findings of the SPSS 20.0 program. Inferential analysis is used to examine the hypothesis. The researcher employed a t-test (testing significance) for an independent sample test in this example, which is a test that establishes the significance of the difference in the average score of students in the experimental and control courses on the pretest and posttest. The results of the calculation of pre-student test t-tests are shown in the table below. The sig-value $(0.457)$ is greater than $=0.05$, as shown in the table above. It indicates that the difference in students' knowledge is statistically small, and that the control group or class has the same or no value.

Table 4 T-test sample independent post test

Independent Samples Test

\begin{tabular}{|c|c|c|c|c|c|c|c|c|c|}
\hline & \multicolumn{2}{|c|}{$\begin{array}{l}\text { Levene's Test for } \\
\text { Equality of Variances }\end{array}$} & \multicolumn{7}{|c|}{ t-test for Equality of Means } \\
\hline & \multirow[b]{2}{*}{$\mathrm{F}$} & \multirow[b]{2}{*}{ Sig. } & \multirow[b]{2}{*}{$\mathrm{t}$} & \multirow[b]{2}{*}{ df } & \multirow{2}{*}{$\begin{array}{c}\text { Sig. } \\
(2- \\
\text { tailed) }\end{array}$} & \multirow[b]{2}{*}{$\begin{array}{c}\text { Mean } \\
\text { Difference }\end{array}$} & \multirow[b]{2}{*}{$\begin{array}{l}\text { Std. Error } \\
\text { Difference }\end{array}$} & \multicolumn{2}{|c|}{$\begin{array}{c}95 \% \\
\text { Confidence } \\
\text { Interval of the } \\
\text { Difference } \\
\end{array}$} \\
\hline & & & & & & & & Lower & $\begin{array}{l}\text { Upp } \\
\text { er }\end{array}$ \\
\hline $\begin{array}{ll}P & \text { Equal } \\
\text { o } & \text { variances } \\
\text { st } & \text { assumed } \\
\text { te } & \text { Equal } \\
\text { st } & \text { variances } \\
& \text { not } \\
& \text { assumed }\end{array}$ & 9.335 & .003 & $\begin{array}{r}12.448 \\
12.448\end{array}$ & $\begin{array}{r}58 \\
44.572\end{array}$ & .000 & 14.16667 & 1.13807 & $\begin{array}{r}11.8885 \\
7 \\
\\
11.8738 \\
6\end{array}$ & $\begin{array}{r}16 . \\
444 \\
77 \\
\\
16 . \\
459 \\
47\end{array}$ \\
\hline
\end{tabular}

The P-value $(0.03)$ is lower than $=0.05(0.00$ is small than 0.05 ) in the table above. It denotes a statistically significant change in students' comprehension before and after utilizing the video scribe application to study. On the basis of the foregoing data and discussion, hypothesis $\mathrm{H} 1$ is supported and hypothesis Ho is rejected.

\section{CONCLUSION}

Based on the information in the preceding chapter, it can be inferred that using scribe video programs in the learning process in MTs Banua Sendana pupils after they have been treated can help them enhance their English abilities. This is evident in the results of the experimental class posttest which is higher than the value in the class or control group $(85.00>79.00)$. so, it was concluded that the use of the video scribe 
application was very effective for improving students' English skills.

\section{REFERENCES}

[1] Arsyad, Azhar. (2002). Media Pembelajaran. Jakarta: PT Raja Grafindo Persada.

[2] Asep Jihad, Abdul Haris. (2012:14) Prestasi belajar dan Evaluasi Pembelajaran. Yogyakarta:Multi Pressindo.

[3] Anita. Method of Teaching English (Refleksi Macam-macam Metode Mengajar.Syarifahkamilasari.blogspot.com. diakses pada tanggal 4 juli 2016.

[4] Gay, L.R. 2006. Educational Research, Competencies for Analysis and Application. Columbus, Ohio. Pearson Merrill Prentice Hall. http://www.wirahadie.com/2016/05/caramembuat-video-scribe-dengan-

aplikasisparkol.html/diakses 28 maret 2018
[6] Richards and Rodgers. 1995. Approaches and Methods in Language Teaching. Cambridge University Press.

[7] Story telling-wikipedia bahasa Indonesia, ensiklopedia bebas. Diakses pada tanggal 4 Juli 2016.

[8] Sudijono, Anas. 2006. Pengantar Statistic Pendidikan. Jakarta: PT Raja Grafindo

[9] Sadiman, AS. (2008:7). Media Pendidikan. Jakarta: PT. Raja Grafindo Persada.

[10] Sudrajat, Akhmad. (2008). Pendekatan Strategi Metode Teknik dan Model Pembelajaran. Vol(2).

[11] Wulandari, Dyah Ayu.(2016). Pengembangan Media Pembelajaran Menggunakan Sparkol Videoscribe Dalam Meningkatkan Minat Belajar Siswa PadaMata Pelajaran IPA Materi Cahaya Kelas VIII di SMP Negeri 01 Kerjo Tahun2015/2016. (http//:lib.unnes.ac.id.html, diakses 20 Maret2018). 